\title{
PEMANFAATAN BERAS MERAH DAN JAGUNG DALAM PEMBUATAN MIE SEBAGAI BAHAN PANGAN FUNGSIONAL
}

\author{
Ernawati Nasution $^{1}$, Etti Sudaryati ${ }^{2}$, Asfriyati $^{3}$ \\ ${ }^{1,2,3}$ Fakultas Kesehatan Masyarakat, Universitas Sumatera Utara, Medan, Indonesia \\ E-mail : nasutionernawati38@yahoo.com
}

\begin{abstract}
Abstrak. Beras merah dan jagung sudah lama diketahui bermanfaat bagi kesehatan, selain sebagai pangan pokok. Namun beras merah dan jagung kurang populer sebagai makanan pokok masyarakat padahal kedua jenis pangan ini merupakan pangan fungsional yang sangat berguna. Maka dikenalkan cara lain untuk pemanfaatan kedua bahan ini dengan mengolahnya menjadi tepung beras merah dan tepung jagung untuk pembuatan mie.

Metode. Metode yang digunakan dalam pelatihan ini adalah ceramah dan praktek. Praktek dilakukan untuk memberikan keterampilan kepada masyarakat dalam membuat mie dari tepung beras merah dan tepung jagung.

Hasil.. Praktek pembuatan mie tepung beras merah dan tepung jagung yang dilakukan juga berhasil menambah pengetahuan dan keterampilan peserta dalam pengolahan beras merah dan jagung. Pelatihan yang telah dilakukan ini memberikan pemahaman dan keterampilan kepada masyarakat di wilayah kerja Puskesmas Terjun Marelan, dalam pemanfaatan beras merah dan jagung yang diolah menjadi tepung sebagai bahan untuk pembuatan mie yang merupakan pangan fungsional

Impilikasi yang dihasilkan. Termanfaatnya beras merah dan jagung yang dibuat menjadi tepung sebagai bahan pembuatan mie sebagai pangan yang fungsional. Diharapkan peran aktif peserta untuk menyebarluaskan informasi tentang pemanfaatan beras merah dan jagung kepada masyarakat di sekitar mereka.
\end{abstract}

\section{Pendahuluan}

Tidak optimalnya konsumsi beras merah dan jagung dengan baik oleh masyarakat. Hanya segelintir orang saja yang mau mengonsumsi beras merah dan jagung. Pemanfaatan beras merah dan jagung menjadi tepung sebagai bahan olahan pembuat makanan salah satunya menjadi mie. Mie merupakan salah satu makanan yang digemari oleh masyarakat tetapi masih sedikit yang dapat mengolah mie sendiri di rumah dengan beragam modifikasi, sehingga masyarakat hanya mengenal mie yang terjual di pasaran.

Mie yang terbuat dari tepung beras merah dan tepung jagung dapat meningkatkan kualitas mutu mie basah yang dihasilkan terutama dalam kandungan gizi. Warna tepung jagung yang kuning dapat membuat warna mie yang dihasilkan menjadi menarik tanpa harus menggunakan pewarna buatan, sehingga masyarakat yang gemar mengonsumsi mie tidak perlu ragu dan khawatir karena tetap bisa mengonsumsi mie yang sehat serta bergizi tinggi. Banyaknya masyarakat mulai dari anak kecil hingga dewasa yang menyukai mie memberikan peluang besar untuk memanfaatkan beras merah dan jagung sebagai bahan baku pembuatan mie dan dapat dipromosikan kepada masyarakat luas mengingat bahan baku tersebut mudah untuk ditemukan. Selain itu, pengolahan dan pemanfaatan beras merah dan jagung ini juga merupakan upaya yang mendukung program diversifikasi pangan.

Kegiatan pengabdian masyarakat ini merupakan intervensi di bidang gizi melalui pelatihan pembuatan mie yang terbuat dari tepung beras merah dan tepung jagung kepada masyarakat di wilayah kerja Puskesmas Terjun Marelan. Kegiatan pelatihan ini bertujuan untuk memberikan pemahaman dan keterampilan kepada masyarakat di wilayah kerja Puskesmas Terjun Marelan dalam pemanfaatan tepung beras merah dan tepung jagung sebagai bahan dalam pembuatan mie 


\section{Bahan dan Metode}

\subsection{Lokasi Pengabdian}

Pengabdian kepada masyarakat ini dilakukan di wilayah kerja Puskesmas Terjun Marelan tepatnya di Kelurahan Labuhan Deli Kecamatan Medan Marelan. Kelurahan ini merupakan salah satu wilayah kerja dari Puskesmas Terjun.

\subsection{Metode}

Kegiatan ini dilakukan dalam bentuk pelatihan dengan metode ceramah dan praktek. Ceramah dilakukan dalam hal pemberian materi tentang kandungan gizi dari beras merah dan jagung, pemanfaatan beras merah dan jagung dalam pengolahan makanan, pengolahan beras merah dan jagung menjadi tepung, dan pemanfaatan tepung beras merah dan tepung jagung dalam pengolahan pangan. Pada kegiatan ini dilakukan praktek

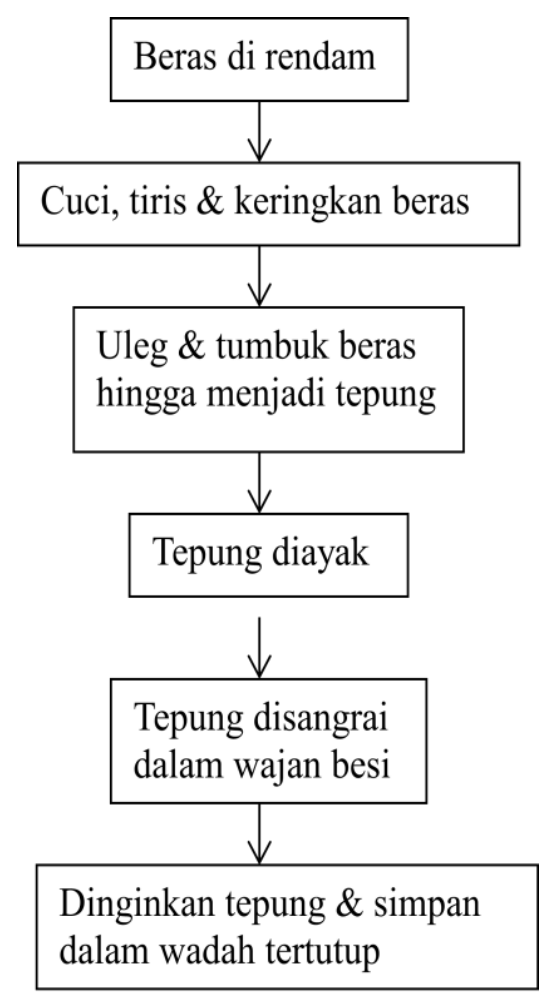

Gambar 1. Skema Pembuatan Tepung Beras Merah pembuatan mie yang terbuat dari tepung beras merah dan tepung jagung. Secara rinci kegiatan yang dilakukan dalam pelatihan ini adalah sebagai berikut:

1. Pemberian pemahaman tentang keunggulan beras merah dan jagung dari aspek gizi, dan perannya sebagai peningkatan status gizi dan status kesehatan masyarakat.

2. Pemberian pemahamam proses pembuatan pangan fungsional seperti mie dari beras merah dan jagung.

3. Praktek atau latihan pembuatan tepung beras merah dan tepung jagung dan pembuatan mie dari kedua tepung tersebut.

4. Pemberian pelatihan dan pendampingan pemasaran produk.

Tahapan dalam pembuatan tepung beras merah dan tepung jagung adalah sebagai berikut :

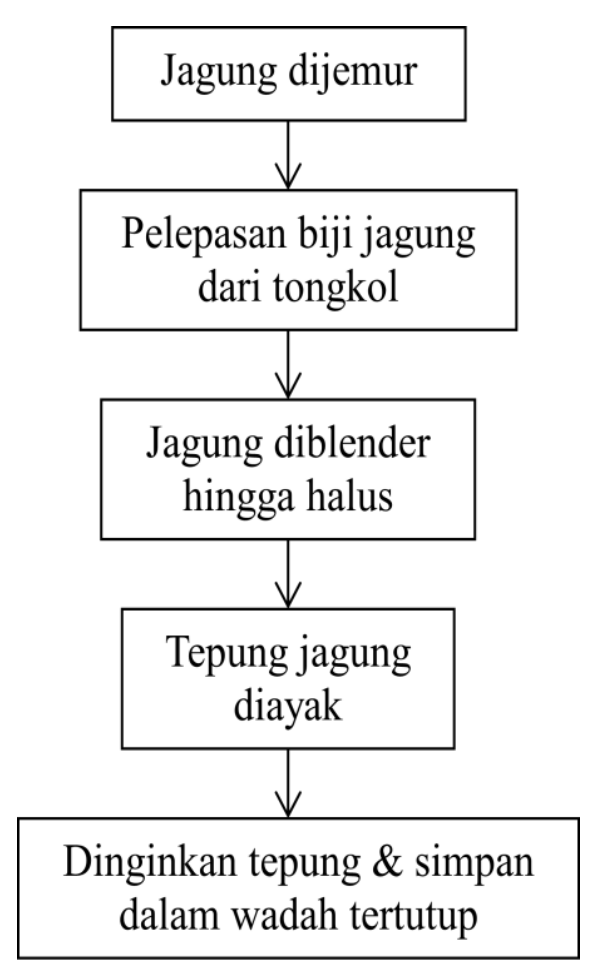

Gambar 2. Skema Pembuatan Tepung Jagung 
Ernawati Nasution. et al. Pemanfaatan Beras Merah Dan Jagung Dalam Pembuatan Mie...

Proses pembutan mie dapat dilihat pada gambar berikut.

Berikut skema dalam pembuatan mie:

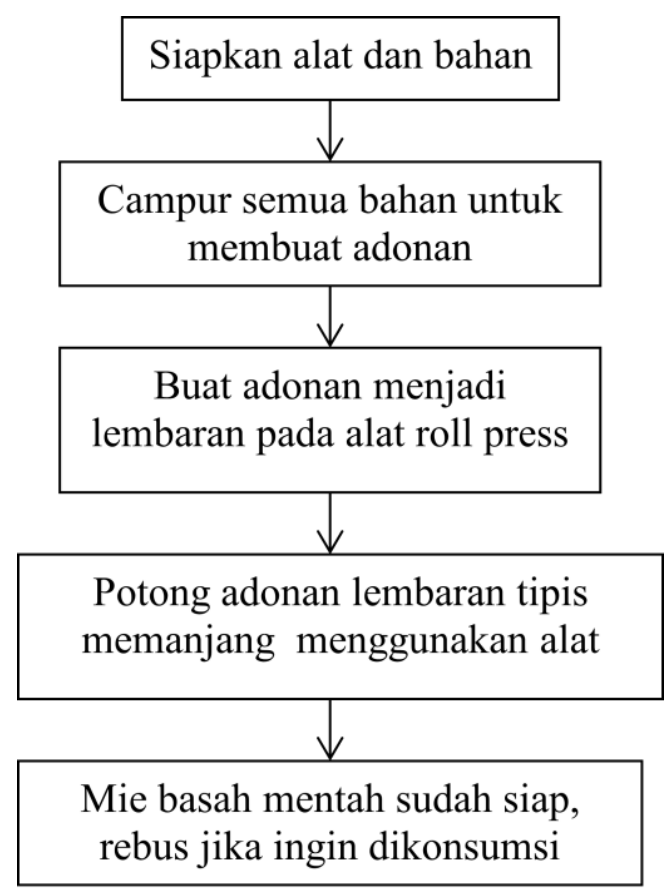

Gambar 3. Skema Pembuatan Mie

\section{Hasil dan Pembahasan}

Pelatihan dimulai penyampaian materi tentang jagung dan beras merah yang meliputi kandunganr gizi dan pemanfaatan serta cara pengolahannya. Kemudian dilanjutkan dengan praktek pembuatan mie tepung beras merah dan tepung jagung. Kegiatan diikuti para peserta dengan baik karena mereka selama ini tidak pernah berfikir bahwa tepung beras merah dan tepung jagung bisa dibuat mie dengan hasil yang sama seperti mie yang terbuat dari tepung terigu. Tepung jagung yang berwarna kuning menghasilkan mie dengan warna yang menarik. Penggunaan tepung jagung dalam pembuat mie juga bisa menghindari penggunaan pewarna dalam proses pembuata mie.

Pelatihan pembuatan tepung beras merah dan tepung jagung dan praktek pembuatan mie dilakukan pada hari yang sama. Sedangkan pelatihan pemasaran produk yang dihasilkan diberikan pada kelompok masyarakat yang ada di wilayah kerja Puskesmas Terjun Marelan ini sebagai tambahan pengetahuan jika produk yang dihasilkan nantinya akan dipasarkan. Pelatihan manajemen pemasaran produk diberikan dalam sehari pada kelompok tersebut. Kegiatan pelatihan pembuagtan mie dapat dilihat pada gambar berikut. 

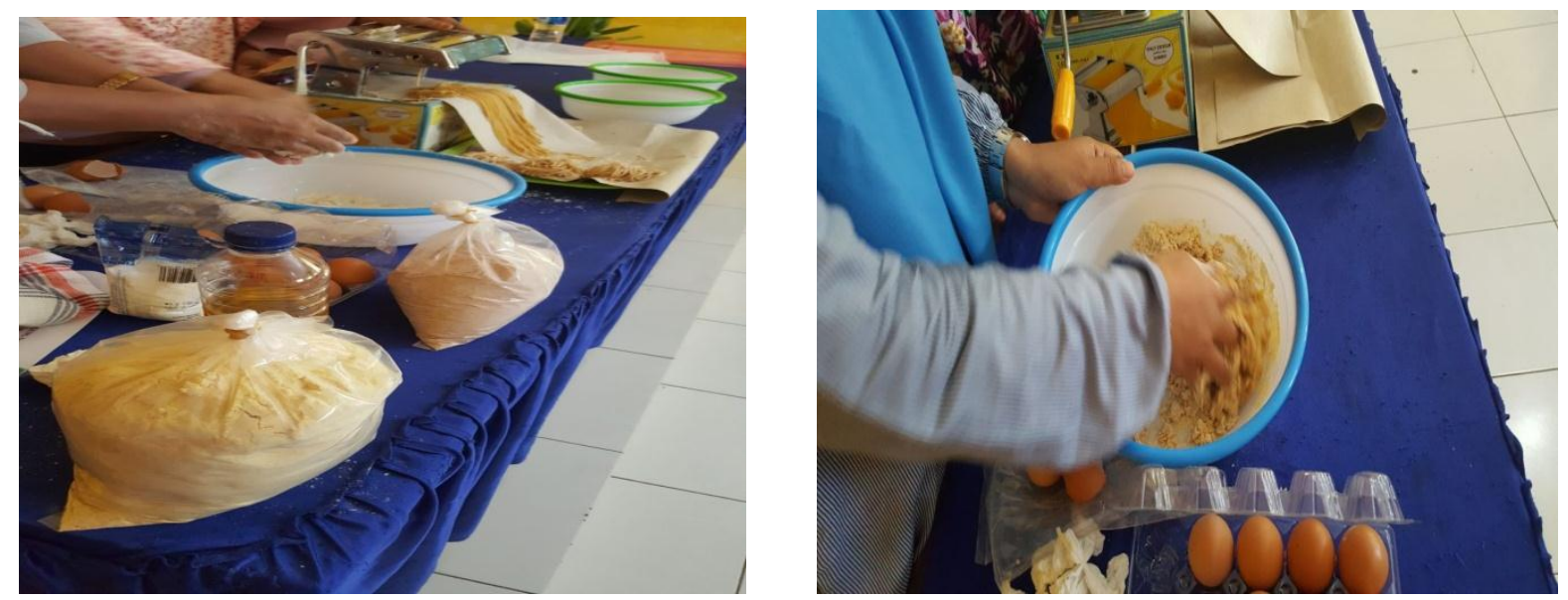

Gambar 3. Bahan - bahan Pembuatan Mie

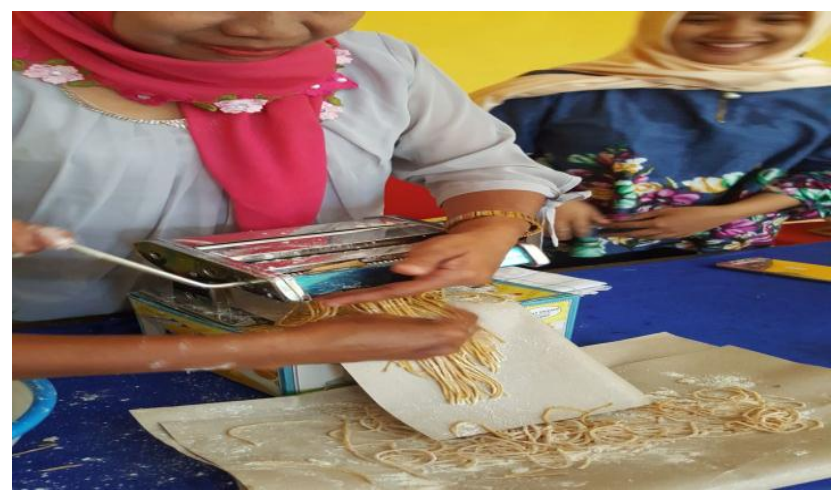

Gambar 4. Proses Pembuatan Mie.

Hasil yang sudah dicapai dalam pengabdian ini adalah memperkenalkan teknologi sederhana dalam pembuatan tepung beras merah dan tepung jagung yang kemudian tepung tersebut dapat diolah sebagai bahan pangan bergizi.

\section{Kesimpulan dan Saran}

Dari kegiatan pelatihan yang telah dilakukan ini dapat disimpulkan bahwa masyarakat Kelurahan Labuhan Deli dapat memahami pemanfaatan beras merah dan jagung sebagai bahan makanan yang juga dapat diolah menjadi mie yang kandungan gizinya lebih lengkap jika dibandingkan dengan mie yang terbuat dari tepung terigu saja. Mie yang dihasilkan ini juga dapat meningkatkan ketahanan pangan keluarga dengan memanfaatkan bahan pangan lokal yang dapat diperoleh dengan mudah di daerah setempat.

Diharapkan peran aktif peserta untuk menyebarluaskan informasi tentang pemanfaatan beras merah dan jagung yang diolah sebagai tepung untuk bahan pembuatan mie kepada masyarakat di sekitar mereka. Diharapkan masyarakat dapat melanjutkan pembuatan mie yang merupakan pangan bergizi yang terbuat dari tepung beras merah dan tepung jagung ini dan memasarkannya, sehingga dapat menjadi mata pencaharian tambahan dan menambah penghasilan keluarga. Harapan ke depannya kegiatan ini dapat menjadi program yang berkelanjutan, dan membuka kesadaran pihak pimpinan masyarakat di lokasi pengabdian ini agar mendukung kegiatan masyarakat ini yang telah diawali dari perguruan tinggi. 


\section{Ucapan Terima Kasih}

Pada kesempatan ini, penulis mengucapkan terima kasih kepada Lembaga Penelitian Pada Pengabdian Masyarakat Universitas Sumatera Utara yang telah membiayai pengabdian ini melalui Dana PNBP Tahun anggaran 2017 (Kontrak perjanjian Nomor. 3221/UN5.2.3.2.1/PPM/2017, Tanggal 24 Juli 2017) , Fakultas Kesehatan Masyarakat Universitas Sumatera Utara, Masyarakat Wilayah Kerja Puskesmas Terjun Marelan Kecamatan Medan Marelan Kota medan, dan semua pihak yang telah membantu dalam pelaksanaan kegiatan pengabdian pada masyarakat ini

\section{Daftar Pustaka}

1. Aini, N., 2013. Teknologi Fermentasi Pada Tepung Jagung. Edisi Pertama, Graha Ilmu Yogyakarta. Hal. 1-2.

2. Analianasari., dan Zaini, M., 2016. Pemanfaatan Jagung Manis Dan Kulit Buah Naga Untuk Olahan Mie Kering Kaya Nutrisi. Jurnal Penelitian Pertanian Terapan. 16 (2): 123-131.

3. APTINDO (Asosiasi Produsen Tepung Terigu Indonesia), 2016. Indonesia Wheat Flour Consumption and Growth. aptindo.or.id (akses 21 Maret 2017)

4. Arief, R.N., Yani, A., Asropi., Dewi, F., 2014. Kajian Pembuatan Tepung Jagung dengan Proses Pengolahan Yang Berbeda. Di dalam: Prosiding Seminar Nasional "Inovasi Teknologi Pertanian Spesifik Lokasi”. Balai Pengkajian Teknologi Pertanian (BPTP) Lampung. p.611-617.

5. Aristyanto, B., 2013. Uji Organoleptik Hasil Jadi Mi Menggunakan Tepung Beras Merah. Tesis, Universitas Bina Nusantara, Jakarta.

6. Badan Pusat Statistik, 2017. Rata-Rata Konsumsi per Kapita Seminggu Beberapa Macam Bahan Makanan Penting, 20072015. bps.go.id (akses 17 Mei 2017, 22.30)
7. Ekafitri, R., 2010. Teknologi Pengolahan Mie Jagung: Upaya Menunjang Ketahanan Pangan Indonesia. Balai Besar Pengembangan Teknologi Tepat Guna, LIPI. PANGAN. 19 (3): 283-293.

8. Humaedah, U., 2014. Aek Sibundong, Varietas Unggul Padi Beras Merah. Kementerian Pertanian Badan Penyuluhan dan Pengembangan Sumber Daya Manusia Pertanian. cybex.pertanian.go.id (akses 5 Maret 2017).

9. Indrasari, S.D., 2006. Padi Aek Sibundong: Pangan Fungsional. Di dalam: Warta Penelitian dan Pengembangan Pertanian.

10. Indrasari, S.D., dan Adnyana, M.O., 2007. Preferensi Konsumen terhadap Beras Merah sebagai Sumber Pangan Fungsional. Jurnal Iptek Tanaman Pangan. 2 (2): 228 .

11. Kristamtini., dan Purwaningsih, H., 2009. Potensi Pengembangan Beras Merah Sebagai Plasma Nutfah Yogyakarta. Jurnal Litbang Pertanian. 28 (3): 88.

12. Moeljaningsih., 2011. Kajian Tentang Penggunaan Tepung Jagung pada Pembuatan Kue Kering. Berita Litbang Industri. Volume XLVI (I):30-35.

13. Richana, N., 2010. Tepung Jagung Termodifikasi sebagai Pengganti Terigu. Warta Penelitian dan Pengembangan Penelitian. 32 (6): 5-7.

14. Riyanto, C., Purwijantiningsih, L.M.E., Pranata, F.S., 2014. Kualitas Mi Basah dengan Kombinasi Edamame (Glycine $\max$ (L.) Merrill) dan Bekatul Beras Merah. Jurnal Teknobiologi. Atma Jaya Yogyakarta. p.1-22.

15. Subekti, A., 2015. Karakteristik dan Pola Kekerabatan Plasma Nutfah Padi Beras Merah di Kalimantan Barat. Di dalam: Prosiding Seminar Nasional Sumber Daya 
Ernawati Nasution. et al. Pemanfaatan Beras Merah Dan Jagung Dalam Pembuatan Mie...

Genetik Pertanian. Balai Pengkajian Teknologi Pertanian Kalimantan Barat. p.118-119.

16. Suliartini, N.W.S., Sadimantara, G.R., Wijayanto, T., dan Muhidin., 2011. Pengujian Kadar Antosianin Padi Gogo Beras Merah Hasil Koleksi Plasma Nutfah Sulawesi Tenggara. Jurnal Crop Agro. 4 (2): 44.
17. Wijayanti, I., 2015. Eksperimen Pembuatan Kue Semprit Tepung Beras Merah. Skripsi, Universitas Negeri Semarang, Semarang.

18. Yuliati, L.N., Retnaningsih., Aprilia, D, 2012. Pengaruh Kelompok Acuan Terhadap Kesadaran dan Konsumsi Beras Merah (Oryza nivara). Jurnal Ilmu Keluarga dan Konsumen. 4 (2): 169. 